\title{
Early Field Performance of Small-Sized Silver Birch and Scots Pine Container Seedlings at Different Planting Depths
}

\author{
Laura Pikkarainen ${ }^{1, *(\mathbb{D},}$, Jaana Luoranen ${ }^{2} \mathbb{D}$ and Heli Peltola ${ }^{1}(\mathbb{D}$ \\ 1 Faculty of Forest Sciences, University of Eastern Finland, P.O. Box 111, FI-80101 Joensuu, Finland; \\ heli.peltola@uef.fi \\ 2 Natural Resources Institute Finland (Luke), Production Systems, Juntintie 154, FI-77600 Suonenjoki, Finland; \\ jaana.luoranen@luke.fi \\ * Correspondence: laura.pikkarainen@uef.fi
}

Citation: Pikkarainen, L.; Luoranen, J.; Peltola, H. Early Field Performance of Small-Sized Silver Birch and Scots Pine Container Seedlings at Different Planting Depths. Forests 2021, 12, 519. https://doi.org/10.3390/f12050519

Academic Editor: Adele Muscolo

Received: 1 April 2021

Accepted: 21 April 2021

Published: 22 April 2021

Publisher's Note: MDPI stays neutral with regard to jurisdictional claims in published maps and institutional affiliations.

Copyright: (c) 2021 by the authors. Licensee MDPI, Basel, Switzerland. This article is an open access article distributed under the terms and conditions of the Creative Commons Attribution (CC BY) license (https:/ / creativecommons.org/licenses/by/ $4.0 /)$.

\begin{abstract}
Deep planting is recommended in Nordic countries only for normal-sized container seedlings planted on mounds. Its effects on smaller-sized seedlings are poorly understood. We studied the effects of planting depth on the early field performance of small-sized silver birch (Betula pendula Roth) and Scots pine (Pinus sylvestris L.) container seedlings. Silver birch seedlings (mean height of $16 \mathrm{~cm}$ ) were planted to depths of 3,6 and $8 \mathrm{~cm}$ on spot mounds in May 2016. Scots pine seedlings (mean height of $9 \mathrm{~cm}$ ) were planted to depths of 2, 5 and $8 \mathrm{~cm}$ on inverted mounds in September 2018 and May 2019. At the end of the first growing season, the deeper-planted birch seedlings were the tallest, as opposed to the deeper-planted Scots pine seedlings. However, the height differences between the planting depths were not apparent until the end of the second growing season in both tree species. Deeper planting decreased damage in Scots pine seedlings in the first growing season, which was not observed in silver birch. Based on our findings, small-sized Scots pine and silver birch seedlings can be planted safely at $6-8 \mathrm{~cm}$ planting depths, if at least $20 \%$ and $50 \%$ of their shoots, respectively, are above ground.
\end{abstract}

Keywords: Betula pendula; Pinus sylvestris; field performance; deep planting; small-sized seedling

\section{Introduction}

In Finland, nurseries produce about 160 million container seedlings annually for planting in forest regeneration areas. In Finland, the majority (ca. 67\%) of all annuallyplanted seedlings are currently container-grown Norway spruce (Picea abies (L.) Karst.) seedlings. The rest are Scots pine (Pinus sylvestris L., 30\%) and silver birch (Betula pendula Roth, $3 \%$ ) seedlings [1]. However, there is pressure to increase the proportion of Scots pine and silver birch (and also other tree species) in the plantings and decrease that of Norway spruce. This is needed in order to increase the species diversity and, consequently, forest resilience to multiple abiotic and biotic damage risks, which are expected to increase in Norway spruce, in particular, in boreal regions under a changing climate [2-4].

In the past, silver birch seedlings were grown in Finnish nurseries in large-volume containers (cell volume $200-400 \mathrm{~cm}^{3}$ ) and were $40-60 \mathrm{~cm}$ tall at the time of planting [5]. However, Luoranen et al. [5] showed that silver birch seedlings can also be grown in smaller-volume containers (cell volume $80-120 \mathrm{~cm}^{3}$ ) for a short time, and then planted when the seedlings are about $15-30 \mathrm{~cm}$ tall. These shorter silver birch seedlings (with smaller-volume peat plugs) can also be planted using a planting tube, as opposed to tall seedlings with large-volume plugs that need to be planted in a hole. For Scots pine, oneyear-old seedlings grown in containers with medium-sized cell volumes $\left(80-90 \mathrm{~cm}^{3}\right)$ have typically been used in plantings in Finland and Sweden. However, in northern Finland and Sweden, smaller, ca. 10-week-old and 5-10-cm-tall (cell volume $15-40 \mathrm{~cm}^{3}$ ) containergrown Scots pine seedlings have also been used in forest regeneration [6,7]. For both tree species, smaller-sized seedlings are cheaper to produce due to their shorter growing period 
in nurseries. Following that, they require less space in both storage and transportation, and are easier to plant.

In certain previous studies, small-sized Scots pine seedlings have also been observed to grow at least as well, and suffer less pine weevil damage, compared to larger-sized container seedlings $[6,8,9]$. However, they have been found to be more prone to storage and environmental stress factors, such as drought [8,10-12]. To date, small-sized Scots pine seedlings have been used in forest regeneration mainly in the humid climate of the northern parts of Nordic countries. However, because of their many benefits, they could also be an attractive option as forest regeneration material in other parts of Nordic boreal forests.

These days, spot mounding and inverting are largely used in the planting of seedlings in Nordic countries [13]. In spot mounding, the humus and underlying mineral soil is removed and flipped over onto the adjacent undisturbed forest floor. In inverting, the layered soil is, instead, returned to the planting pit upside down [14]. Based on previous studies, seedlings should preferably be planted deep enough that the peat plug is in the humus layer [15]. Currently, the recommended typical planting depth is $5 \mathrm{~cm}$ for conventional container seedlings when using spot mounding or inverting. In silver birch, there has been a worry that deep planting may disturb the development of the seedlings, as well as increase the risk of birch stem spot fungi. In deep planting, almost the whole shoot may need to be placed below ground in small-sized seedlings (e.g., Scots pine), in order to have the peat plug sit in the humus layer below a mound.

In previous early-performance studies on hybrid larch (Larix x marschlinsii Coaz) [16], oak (Quercus robur L.) and beech (Fagus sylvatica L.) [17] seedlings, deep planting did not decrease height growth of seedlings. In long-term planting-depth experiments, planting depth did not affect total diameter or height growth in seedlings of black spruce (Picea mariana (Mill.) B.S.P.), white spruce (Picea glauca (Moench) Voss) or jack pine (Pinus banksiana L.) over a 19-year period since forest regeneration [18]. Tarroux et al. [19] even found deep planting to increase total height and diameter growth in white spruce and height growth in black spruce (which showed no effect on diameter growth) over a 17-year period since forest regeneration. Based on these studies, it seems that the growth of seedlings in many conifer and broadleaved species could either benefit, or at least would not suffer, from deep planting.

In Finland, conifer seedlings are also typically planted in a narrow window, from May to early June, which causes significant work pressure for seedling producers, planting organizers, and manual and machine planters [20,21]. Therefore, the interest in extending the planting window of conifer seedlings throughout the unfrozen growing season has increased. However, it is not recommended to plant Scots pine container seedlings in mid-summer due to their poor performance [22,23]. Autumn-planted Scots pine seedlings perform better when planted without prior field storage, and when winter weather conditions are not too harsh after planting [24,25]. Overall, Scots pine seedlings seem to be more sensitive to different damage-causing factors compared to Norway spruce seedlings [11,26]. They are also typically planted on coarse-textured soils, where the risk of drought is naturally higher than on moist, finer-textured soils.

Adopting planting procedures, for example, by deepening the planting depth, may also mitigate the risks related to environmental and other stress factors (e.g., drought, insect pests) in different planting seasons and thus increase the success of forest regeneration. In previous studies, the deep planting of one- and two-year-old conventional conifer seedlings (with height $>15 \mathrm{~cm}$ ) in spring enhanced both their growth and survival, and protected the seedlings from pine weevil feeding and drought damage [27-29]. However, we do not yet know if deep planting could be of benefit in autumn plantings by, for example, protecting seedlings against drought and winter damage.

In this study, we investigated the effects of planting depth on the early field performance of small-sized silver birch and Scots pine container seedlings in two different experiments. In Experiment 1, silver birch seedlings were grown in peat plugs with cell volume of $85 \mathrm{~cm}^{3}$ and planted in spring. In Experiment 2, Scots pine seedlings were 
grown in peat plugs with cell volume $30 \mathrm{~cm}^{3}$ and planted in both autumn and spring. We hypothesized that the deeper-planted seedlings would grow better than the shallower planted ones if more than $50 \%$ of their shoot length was above ground (providing enough photosynthesizing leaf/needle area). In Experiment 1, our hypothesis was also that there would be no risk of birch-stem spot fungus, even though the greater part of the shoot would be below ground. In Experiment 2, we also hypothesized that: (i) deep planting would give a better protection for the seedlings against abiotic damage, especially drought, than shallower planting; and (ii) the mortality of spring-planted small-sized Scots pine seedlings would be lower than for autumn-planted seedlings.

\section{Materials and Methods}

\subsection{Seedling Materials}

For both experiments, seedlings were grown at the Suonenjoki Research Nursery, run by the Natural Resources Institute of Finland (62 $39^{\prime}$ N, $27^{\circ} 03^{\prime}$ E, $142 \mathrm{~m}$ a.s.l.). For Experiment 1, on silver birch (Betula pendula Roth), seed-orchard-coated seeds (SV 424) for use in Central Finland were sown into hard-walled plastic containers on 22 June 2015 (Plantek PL81F, 81 seedlings per tray, cell volume $85 \mathrm{~cm}^{3}$, growing density 546 cells $\mathrm{m}^{-2}$; BCC, IsoVimma, Finland). The containers were filled with base-fertilized $\left(0.8 \mathrm{~kg} \mathrm{~m}^{-3} 16 \mathrm{~N}: 8 \mathrm{P}: 16 \mathrm{~K}\right.$ soluble fertilizer with micronutrients) and limed $\left(2.0 \mathrm{~kg} \mathrm{~m}^{-3}\right)$ light sphagnum peat (White 420 F6W, Kekkilä Co., Tuusula, Finland). The seedlings were grown in the greenhouse until 27 July 2015, when they were moved to the outdoor growing area. On 21 July, the seedlings were sprayed with fosetyl-aluminium (Aliette, $0.3 \%$ liquid, $600 \mathrm{~L} \mathrm{ha}^{-1}$ ). As they were growing, the seedlings were irrigated daily, but not fertilized. On 28 October 2015, the seedlings were packed into four cardboard boxes and transferred to freezer storage $\left(-3^{\circ} \mathrm{C}\right)$. On 29 April 2016, the seedlings were transferred to $+5{ }^{\circ} \mathrm{C}$ storage.

For Experiment 2, Scots pine seeds (seed orchard SV323 for use in Central Finland) were sown on 6 June 2018 in hard, plastic Airblock (BCC, Landskrona, Sweden) 196F trays (196 cells per tray, 1322 cells $\mathrm{m}^{-2}$, cell volume $30 \mathrm{~cm}^{3}$ ), equipped with air slits and filled with fertilized (Kekkilä Starter6 NPK 16-4-17 $\mathrm{kg} \mathrm{m}^{-3}$ with slow-release N fertilizer and micronutrients) and limed, medium-coarse white sphagnum peat (Kekkilä Oyj, Eurajoki, Finland). The seedlings were grown in a greenhouse at Suonenjoki Research Nursery, under natural light conditions, until 2 August 2018. They were then transferred to an outdoor growing area. The seedlings were irrigated two to seven times per week, depending on the weather conditions. They were given a commercial fertilizer solution (Kekkilä Forest SupereX with 22N:5P:16K) three times from 20 June to 2 August 2018, receiving a total of $19.65 \mathrm{~g} \mathrm{~m}^{-2}$ fertilizer solution. The seedlings were protected against storage mold by Tilt 250 EC ( $0.125 \%$, propiconatsol), applied twice, on 17 August and 13 September 2018. The seedlings for both the autumn (September 2018) and spring (May 2019) plantings were protected against pine weevil feeding by spraying with Karate-Zeon $(0.6 \%$, labda-syhalotrin) on 14 September 2018. On 6 November 2018, the seedlings left for spring planting were packed in cardboard boxes and transferred to freezer storage until 2 May 2019.

\subsection{Planting Trials and Seedling Measurements}

Experiment 1 was performed at Rautalampi $\left(69^{\circ} 45^{\prime}\right.$ N, $49^{\circ} 51^{\prime}$ E) in Finland. The experimental site was mesic and free of stones, and the soil type was partly fine and partly medium-coarse. The regeneration site was spot mounded in autumn 2015. Two edges of the site were also ditched to maintain the water table level low enough even in the wettest time of a year. The silver birch seedlings were planted on 4 May 2016. The target planting depths (length of shoot below ground) were 3,6 and $8 \mathrm{~cm}$. The study design was randomized blocks. There was one seedling from each planting depth in each block. There was a total of 80 blocks, and thus a total of 480 seedlings in the experiment.

The planting site for Experiment 2 was located in Pieksämäki in Finland $\left(62^{\circ} 16^{\prime} \mathrm{N}\right.$, $27^{\circ} 16^{\prime}$ E) and was clear cut in spring 2018. Mechanical site preparation was performed with soil inversion on medium-coarse soil on a sub-xeric site (dryer than other planting 
site). The planting site was also slightly sloped (thus, no problem with high water table) and ditched under the hill. The autumn plantings of small-sized Scots pine seedlings were performed on 25 September 2018 and the spring plantings on 16 May 2019. The study design was split-plot and the field trial consistent of 100 blocks. In each block, there were two plots-one for spring and one for autumn plantings. Inside each of these, we used three planting depths, where $99 \%, 50 \%$ and $25 \%$ of the shoot was below ground. The $99 \%$ planting depth meant that $99 \%$ of the shoot was below ground, with only the apical bud being visible above ground. Six seedlings were planted in each block (three in each sub-plot, and one at each planting depth within each sub-plot), giving a total of 600 seedlings.

In both experiments, the planting spots in the blocks were chosen to be as similar as possible in terms of quality. The planting depths in the blocks or sub-plots were randomized. The planting was performed using planting tubes (Pottiputki ${ }^{\mathrm{TM}}$, BCC, Iso-Vimma, Finland), which were adjusted to accommodate the different planting depths. The quality of the mounds was assessed in both experiments.

In Experiment 1, both the cover (pure mineral soil, mix of humus and mineral soil, and humus) and type of mound (medium-coarse or fine mineral soil, or humus) were assessed. Any harvesting residues or stones under the mounds were recorded. In Experiment 1, the material of the mound surface was mineral soil in $87 \%$ of cases, a mixture of this with humus in $10 \%$ and just humus in 3\%. The soil types in the mounds were medium-coarse, humus and fine in $63 \%, 2 \%$ and $35 \%$ of cases, respectively. There were no branches or stones under the mounds in $47 \%$ of the cases, whereas $52 \%$ of the mounds contained branches and $1 \%$ stones.

In Experiment 2, the quality of the planting spot was defined visually using three quality classes, good, moderate and poor. A planting spot was classified as: (1) good if the mound was clear of branches and stones, and the inverted mound was composed of separate humus and mineral soil layer; (2) moderate if there was a minor amount of individual branches and stones in the mound, or if the mound was a little asymmetrical, with slightly mixed humus and mineral soil layers; and (3) poor if there were several branches or stones in the mound, the inverted mound was not in the middle of the digging hole and/or had mixed humus and mineral soil layers, or the humus layer was too far away/missing completely for the roots of the seedlings to reach. In Experiment 2, the quality of the planting spots was generally good for $92 \%$ of cases, moderate for $7 \%$ and poor for $1 \%$.

In both experiments, the height of the seedlings was measured (to an accuracy of $0.5 \mathrm{~cm}$ ) from the surface of the peat plug to the top of the seedling before planting. After planting, the seedlings were measured again, from ground level to the top of the seedling. Accurate planting depths were calculated as the difference between the seedling height measured before and after planting. At the end of each growing season, the height of each seedling was measured, and the causes and degree of damage (healthy, slightly damaged, dying, dead) were recorded. In Experiment 1, the stem base diameter (to an accuracy of $0.1 \mathrm{~mm}$ ) of the silver birch seedlings was also measured, at $2 \mathrm{~cm}$ above-ground level, at planting, and at the end of the first and third growing seasons. In Experiment 2, 99\% of the shoots were below ground at planting, and so the diameter of the Scots pine seedlings could not be measured. Multiple leaders and drought damage in the current-year shoots of birch seedlings were recorded each year. At the end of the third year, the bases of the silver birch seedlings were also checked for possible stem spot fungus.

In Experiment 2, the soil temperatures at the planting site were measured using $\mathrm{HOBO}$ data loggers (type H08-008-05, Onset Computer Corp., Bourne, MA, USA), with a total of four temperature sensors (type HOBO TMC20-HD), from 15 May to 5 September 2019 and from 1 April to 11 September 2020. Temperatures were taken at each seedling planting depth and from the level of undisturbed soil. The daily mean soil temperatures between 16 and 31 May 2019 were 13,13 and $12.5^{\circ} \mathrm{C}$ at soil depths of 2,5 and $8 \mathrm{~cm}$, respectively. In May 2020, the daily mean soil temperatures were 10,9 and $8{ }^{\circ} \mathrm{C}$ at depths of 2,5 and $8 \mathrm{~cm}$, respectively. The daily mean soil temperature varied less at depths of $8 \mathrm{~cm}$ during 
the growing seasons (from May to August) of 2019 and 2020 than at the shallower depths of 2-5 cm and at ground level (Figure 1, Figure A1). In June and July, the differences in soil temperature were smaller for the different depths (not shown in detail).
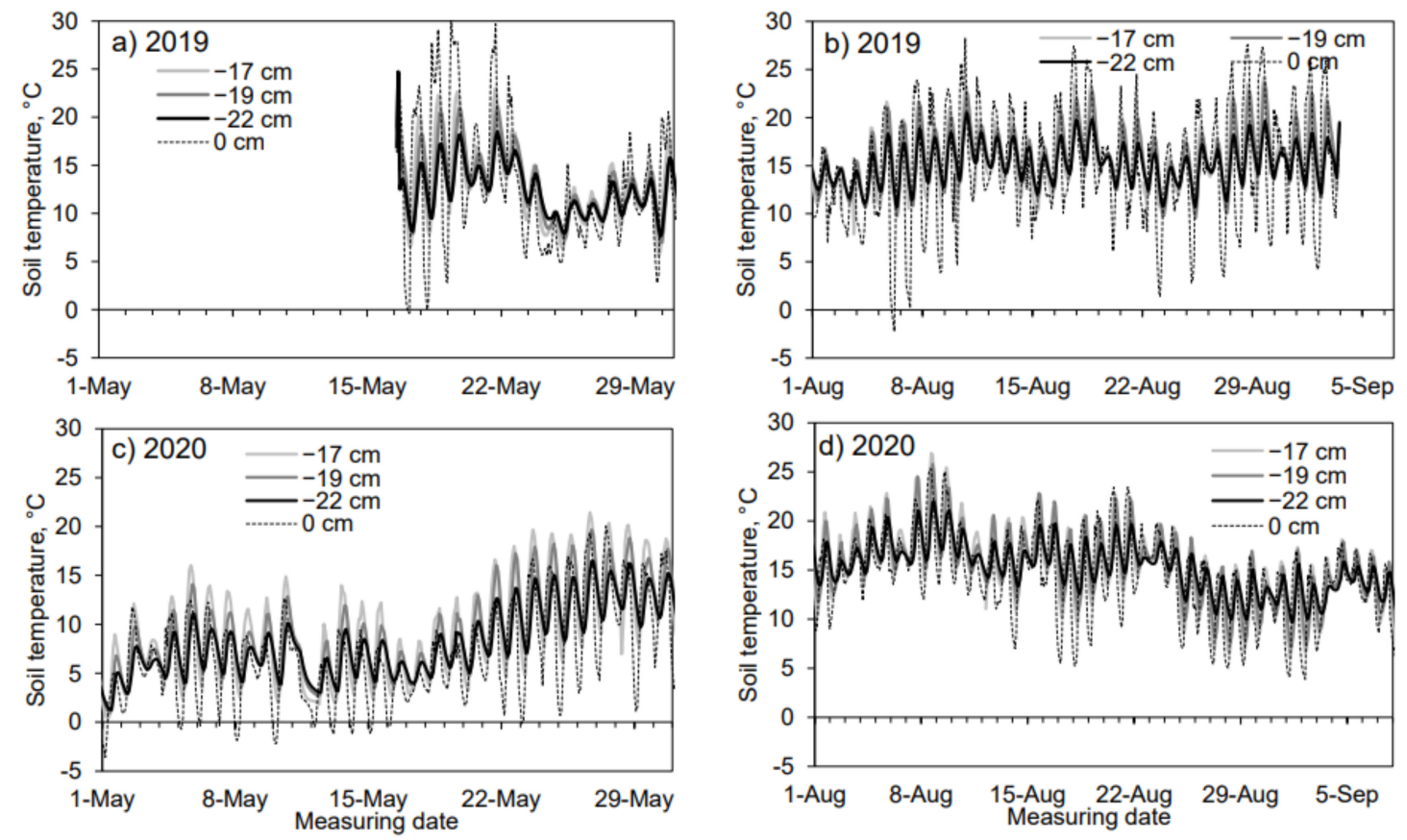

Figure 1. Soil temperatures in spring (a,c) and autumn (b,d) of 2019 and 2020, respectively, at different planting depths in Experiment 2 in Scots pine.

\subsection{Statistical Analysis}

All statistical analyses were performed using IBM SPSS Statistics v.27.0. software. In all the analyses, planting season (S) and planting depth (D) for Scots pine, and planting depth (D) for silver birch were considered as fixed effects, with block being considered as the random effect. The effects on seedling height (both species) and diameter (only in silver birch) were analyzed using a repeated linear mixed model (MIXED). Only healthy and slightly damaged seedlings were included in the height and diameter analyses.

The height and diameter data was checked for normality and the homogeneity of variance was analyzed using Levene's test. In Experiment 2, root square transformation was used to homogenize the variances in shoot height data in Scots pine. Binary data was used to analyze the probability of mortality (with dying seedlings being included in the 'dead' category), multiple leaders, the occurrence of damage (from slightly damaged to dead and missing) and damage from stem spot fungus and moose. The statistical analyses were first performed using a generalized linear mixed model (the GENLINMIX procedure). Because the variance of the random variable (block) was zero, the final statistical analyses applied a generalized linear model (GENLIN), using binominal distribution with a log-link function in the GENLIN model. Multiple comparisons were based on the Bonferroni correction. Differences with a $p$-value $<0.05$ were considered significant.

\section{Results}

\subsection{Experiment 1: Silver Birch Seedlings}

The planting depths (measured part of belowground shoot) were, on average, 3, 6 and $8(\mathrm{SD} \pm 1) \mathrm{cm}$, which corresponded to 81,65 and $51 \%$ of the total aboveground shoot height, respectively. At the end of the first growing season in 2016, the seedlings planted to a depth of $8 \mathrm{~cm}$ were the tallest, being, on average, $64 \mathrm{~cm}$ high $(p<0.05$ for $\mathrm{Y} \times \mathrm{D})$. After the second and third growing seasons, the heights of the seedling were, on average, 
121 and $210 \mathrm{~cm}$. No statistically significant differences were observed in height growth $(p<0.144$ for $\mathrm{D} \times \mathrm{Y}, p<0.123$ for $\mathrm{D} \times \mathrm{Y})$ or diameter growth $(p=0.372$ for $\mathrm{Y} \times \mathrm{D})$ among the planting depths in each year (Figure 2, Table 1).
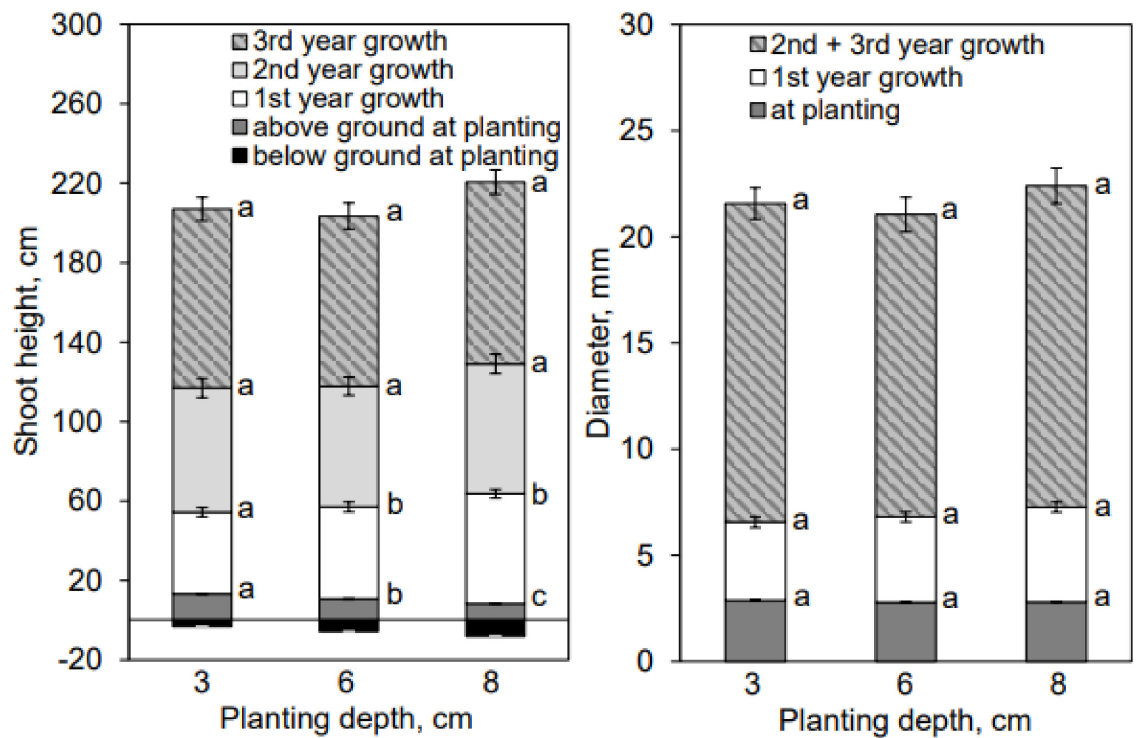

Figure 2. Height (a) and diameter (b) development in silver birch seedlings in 2016-2018 at planting depths of 3, 6 and $8 \mathrm{~cm}$ (length of belowground shoot). The height and diameter of the seedlings were measured at the time of planting, after the first, second (height only) and third growing seasons. Vertical bars indicate the standard error of the means $(n=73-80)$. The different letters indicate statistically significant $(p<0.05)$ differences among planting depths within each year.

Table 1. Repeated (year Y) linear mixed model analysis for the effects of planting depth (D) on the height and diameter of silver birch seedlings. The variance of random effects of each planting year and block are also presented.

\begin{tabular}{|c|c|c|c|c|}
\hline Fixed Effect & $\begin{array}{l}\text { Height } \\
\text { F }\end{array}$ & $p$-Value & $\begin{array}{c}\text { Diameter } \\
\text { F }\end{array}$ & $p$-Value \\
\hline Intercept & 7203.47 & $<0.001$ & 4375.64 & $<0.001$ \\
\hline Planting depth (D) & 4.90 & 0.008 & 1.45 & 0.238 \\
\hline Year $(\mathrm{Y})$ & 1981.03 & $<0.001$ & 1286.13 & $<0.001$ \\
\hline $\mathrm{D} \times \mathrm{Y}$ & 5.31 & $<0.001$ & 1.07 & 0.372 \\
\hline Variance of random effects & Estimate & Std. Error & Estimate & Std. Error \\
\hline At planting & 2.63 & 0.37 & 0.09 & 0.01 \\
\hline First year & 392.80 & 37.74 & 4.66 & 0.43 \\
\hline Second year & 1516.78 & 152.47 & - & - \\
\hline Third year & 2836.91 & 272.37 & 47.08 & 4.44 \\
\hline Block & $<0.01$ & $<0.01$ & - & - \\
\hline
\end{tabular}

After the third growing season in 2018, seedling mortality was low (4\%). Moose browsing damaged $3 \%$ of the seedlings. The other causes of damage were unknown. Planting depth did not statistically significantly affect seedling mortality $(p=0.706)$ or moose grazing $(p=0.873)$. Planting depth also did not significantly affect the probability of the drying of the current-year shoot $(43 \%, p=0.930)$, the occurrence of stem spot fungus $(2 \%, p=0.761)$ or the presence of multiple leaders $(26 \%, p=0.349)$.

\subsection{Experiment 2: Scots Pine Seedlings}

The planting depths (measured part of belowground shoot) were, on average, 2, 5 and $8( \pm 1) \mathrm{cm}$, which corresponded to $77 \%, 47 \%$ and $9 \%$ of the total aboveground shoot height, 
respectively. After the first growing season in 2019, the seedlings with a planting depth of $2 \mathrm{~cm}$ were the tallest, while those with a planting depth of $8 \mathrm{~cm}$ were the shortest in both planting seasons $(p<0.001$ for $\mathrm{S} \times \mathrm{D} \times \mathrm{Y})$. The autumn-planted seedlings were $0.7 \mathrm{~cm}$ taller than the spring-planted seedlings at the end of the first growing season $(p<0.001$ for $S \times Y)$ (Figure 3, Table 2). After the second growing season in 2020, the differences in seedling height were no longer apparent among planting depths within a planting season (autumn $p=0.460$, spring $p=0.425$ for $\mathrm{S} \times \mathrm{D} \times \mathrm{Y})$. However, the autumn-planted seedlings were, on average, $1.7 \mathrm{~cm}$ taller than the spring-planted seedlings $(p<0.05$ for $\mathrm{S} \times \mathrm{Y}$ ) (Figure 3, Table 2).

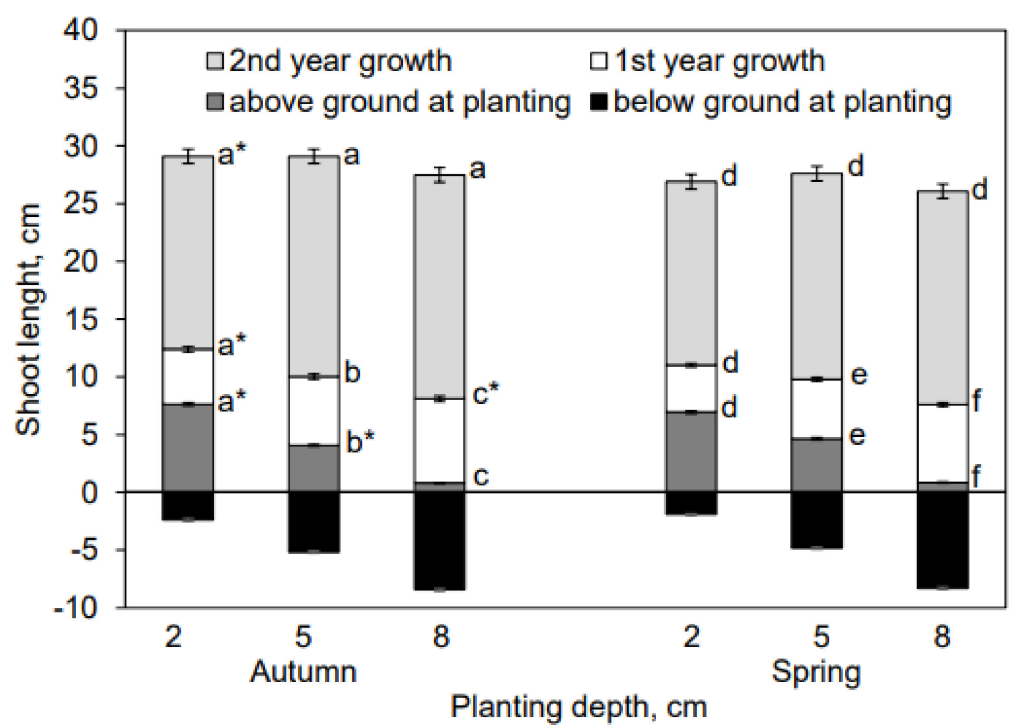

Figure 3. Height development of autumn- and spring-planted Scots pine seedlings in 2019-2020 at planting depths of 2,5 and $8 \mathrm{~cm}$ (length of belowground shoot). The seedlings were measured at the time of planting, and after the first and second growing seasons. Vertical bars indicate the standard error of the means $(n=90-98)$. The different letters indicate statistically significant differences among planting depths in the inventory year. Asterisks $\left(^{*}\right)$ indicate statistically significant differences between the planting seasons at particular planting depths in each year.

Table 2. Repeated (year Y) linear mixed model analysis for the effects of planting depth (D) on the height and diameter of silver birch seedlings. The variance of random effects of each planting year and block are also presented.

\begin{tabular}{|c|c|c|c|c|c|}
\hline Fixed Effect & $\begin{array}{c}\text { Height } \\
\text { F }\end{array}$ & $p$-Value & Random Effects & $\begin{array}{r}\text { Variance of } \\
\text { Estimate }\end{array}$ & Std. Error \\
\hline Intercept & $108,007.438$ & $<0.001$ & At planting & 0.04 & 0.00 \\
\hline Season (S) & 15.104 & 0.002 & First year & 0.09 & 0.01 \\
\hline Planting depth (D) & 589.209 & $<0.001$ & Second year & 0.38 & 0.02 \\
\hline Year $(Y)$ & $11,102.309$ & $<0.001$ & Block & $<0.01$ & $<0.01$ \\
\hline$S \times Y$ & 12.997 & $<0.001$ & & & \\
\hline $\mathrm{D} \times \mathrm{Y}$ & 443.304 & $<0.001$ & & & \\
\hline $\mathrm{S} \times \mathrm{D}$ & 6.443 & 0.004 & & & \\
\hline $\mathrm{S} \times \mathrm{D} \times \mathrm{Y}$ & 1.014 & 0.626 & & & \\
\hline
\end{tabular}

After the first growing season, in 2019, the mortality of autumn-planted Scots pine seedlings was slightly higher ( $5 \%)$ than for spring-planted seedlings $(2 \%)(p=0.023$ for $\mathrm{S}, p=0.851$ for $\mathrm{D}, p=0.794$ for $\mathrm{S} \times \mathrm{D}$ ). After the second growing season in 2020, the seedling mortality was $6 \%(p=0.728$ for $\mathrm{S}, p=0.915$ for $\mathrm{D}, p=0.081$ for $\mathrm{S} \times \mathrm{D})$. After the first growing season in 2019, $6 \%$ of the seedlings were affected by drought, $3 \%$ by insects (web-spinning sawfly, Acantholyda hieroglyphica) and 1\% of the seedlings were missing. The proportion of damaged seedlings (from slightly damaged to dead and missing) decreased 
with planting depth; $15 \%, 11 \%$ and $4 \%$ of the seedlings were damaged at 2,5 and $8 \mathrm{~cm}$ planting depths, respectively ( $p=0.061$ for $\mathrm{S}, p=0.003$ for $\mathrm{D}, p=0.965$ for $\mathrm{S} \times \mathrm{D}$ ) (Figure 4). After the second growing season, in 2020,3\% of the seedlings were affected by fungus (most probably scleroderris canker, Gremmeniella abietina), 3\% by drought, 1\% by insects (web-spinning sawfly and pine weevil, Hylobius abietis) and $1 \%$ by mammals, and $1 \%$ of seedlings were missing $(p=0.594$ for $\mathrm{S}, p=0.439$ for $\mathrm{D}, p=0.299$ for $\mathrm{S} \times \mathrm{D})$.
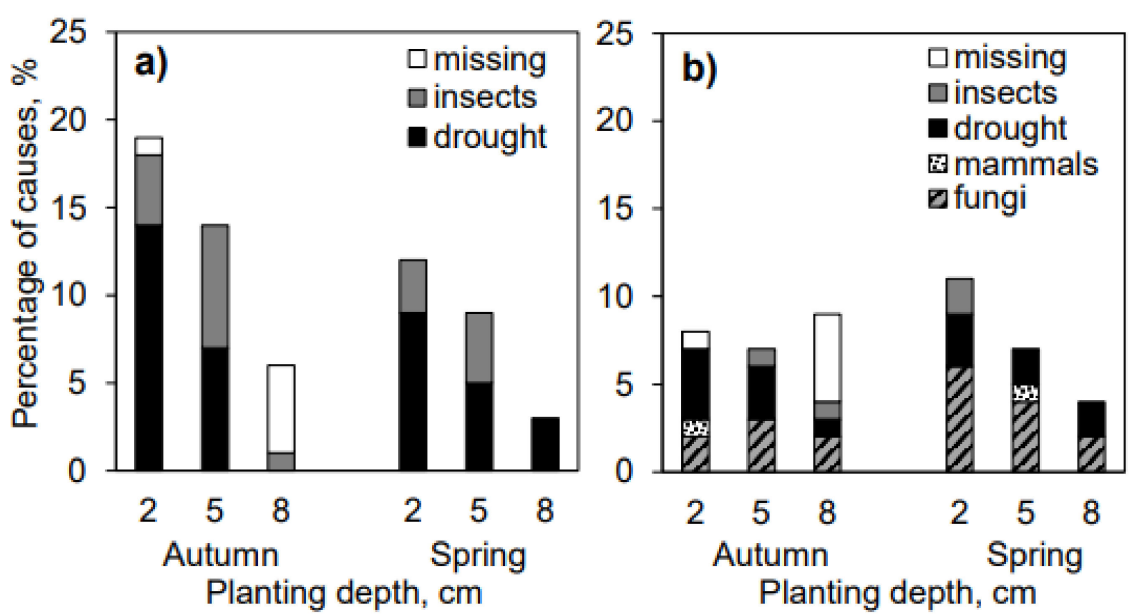

Figure 4. Percentage of causes of damage and missing seedlings in autumn (A) and spring (S) planted Scots pine seedlings (a) after the first (year 2019) and (b) second (year 2020) growing seasons at different planting depths.

\section{Discussion}

The field performance of deeply-planted, small-sized seedlings of silver birch (in spring) and Scots pine (in spring and autumn) was, in general, at least at the same level as it was for shallower-planted seedlings. There were differences in height among planting depths at the end of the first growing season, but they disappeared until the end of the second growing season in both tree species due to the better growth of deeper-planted seedlings in the second growing season. Deep-planted silver birch seedlings [30] and Scots pines can grow adventitious roots from the belowground stem [31,32]. This can increase the root volume in deep-planted seedlings, and also enhance their shoot growth in coming years. Small-sized Scots pine seedlings have also been observed to concentrate more on root growth than height growth during the first year [33]. This may have been the case in our study, as evidenced by large growth differences between successive growing seasons. Unfortunately, we did not measure the root growth in our study.

The autumn-planted Scots pine seedlings grew better than the spring-planted seedlings in the following summer in our study. The soil temperatures during 16-31 May varied between 6 and $25{ }^{\circ} \mathrm{C}$ for all planting depths combined. As a result, the autumn-planted seedlings may have started growth earlier than the spring-planted seedlings, which were transferred from freezer storage $\left(-3^{\circ} \mathrm{C}\right)$ to a temperature of $+5^{\circ} \mathrm{C}$ on 29 April 2019 and planted on 16 May 2019. In addition, Luoranen [25] observed that autumn-planted Scots pine seedlings started their root growth in the following spring when the soil was warmed by only a few degrees. In early September, the minimum soil temperatures at the deepest planting depth were higher than at the shallower depths (e.g., in 2020, from 9 to $6^{\circ} \mathrm{C}$ ) in this study. In line with our findings, Luoranen and Viiri [28] observed higher temperatures at deeper depths in mounds in late autumn. The root growth of seedlings can continue in autumn as long as the soil temperature is above $5^{\circ} \mathrm{C}$ [34]. The longer root growth period may have promoted shoot growth in autumn-planted Scots pine seedlings in our study.

The growing environments of our two experimental sites were different from each other. Scots pine was planted on dryer and less fertile site and silver birch on moister and more fertile site. These are also typical growing environments for these species. Silver birch 
is more water and nutrient demanding (like Norway spruce) than Scots pine. At older age, Scots pine has also in general deeper rooting than Silver birch and it develops especially on sandy soils a taproot, which enhances its anchorage. Silver birch has in general horizontally wider rooting system than Scots pine [35]. It is also deeper than that of Norway spruce.

Luoranen and Viiri [28] reported relatively similar growth patterns in Norway spruce seedlings, under corresponding growing conditions (on medium-coarse and fine-textured soils), as we found in small-sized silver birch and Scots pine seedlings. These findings suggest that deeply-planted seedlings may have better access to the nutrient-rich humus layer compared to shallower-planted seedlings [15]. Luoranen and Viiri [28] also observed enhanced diameter growth in deeply-planted seedlings. Even though we did not find any statistically significant differences after 3 years in diameter growth for silver birch seedlings at different planting depths, the deeply-planted seedlings were the thickest at the end of the experiment.

We found that deeper-planting did not increase the mortality of seedlings either in silver birch or Scots pine, which is in line with earlier findings in conifer and broadleaved seedlings (see, e.g., [16-18]). In addition, Örlander et al. [27] and Luoranen and Viiri [28] suggested that deeper-planted Norway spruce seedlings had less mortality.

Previous studies on the effects of planting depth in Nordic boreal conditions were based on different kind of mounds [27,28]. The purpose of mounding is to improve seedlings' growing conditions by, e.g., increasing the soil porosity, temperature and nutrient availability and decreasing the soil water content (in wet soils) at the root zone [27]. These benefits cannot be obtained, if patching or disc trenching are used, or seedlings are planted on uncultivated soil. Thus, our deep planting results cannot be generalized for those methods.

Although the silver birch seedlings were short $(8-13 \mathrm{~cm})$ at the time of planting, they did not suffer competition from field vegetation at the mesic site. The seedlings grew rapidly in mounds, and were more than $2 \mathrm{~m}$ high at all planting depths at the end of the third growing season. For the silver birch seedlings, the major damaging factor was moose, but the occurrence of moose damage was very low and there were no differences among the planting depths.

In Scots pine, the proportions of drought and insect damage were clearly lower in the deep-planted seedlings after the first growing season, regardless of planting season. Mortality of seedlings was low, although, after the first growing season, the mortality of autumn-planted Scots pine seedlings was 3\% higher than in spring-planted seedlings. This has also been observed in previous studies $[21,26]$. However, autumn plantings have been successful when the seedlings were well watered, carefully planted, handled without field storage, and when no harsh weather conditions occurred at planting (or thereabouts) or during the first winter after planting [24,25].

Based on our findings, deep planting has the potential of being a protective method, especially for Scots pine, against abiotic stressors, such as drought, the occurrence of which is expected to increase under changing climate in boreal regions in spring and summer [36]. In previous studies, deep planting has also been found to decrease drought damage in Norway spruce seedlings $[27,28]$. This is important, especially for small-sized conifer seedlings, which are more sensitive to the stresses caused by environmental factors, seedling handling and competition with field vegetation compared to conventional seedlings [10]. Because the seedlings were small sized in our study, great proportion of the shoot of deep-planted seedlings was underground ( $80 \%$ for Scots pine and $60 \%$ for silver birch) and thus made the seedlings more stable. However, the use of small-sized seedlings might not be a suitable option for conifer species on fertile and moist sites because of the high vegetative competition $[10,11]$. In the study of Tuttle et al. [37], for example, the regeneration results for small loblolly pine (Pinus taeda L.) bare-root seedlings were better than for taller seedlings (seedling heights at planting ranged from 5 to $36 \mathrm{~cm}$ ) on dry sites, as opposed to more moist (fertile) sites. Our results highlight the importance of appropriate planting depth, especially in autumn plantings where the failure risk is higher [21,26]. 
We observed a large number of Scots pine seedlings with feeding web-spinning flies after the first year at shallower planting depths. However, we found only a few feeding scars by pine weevils in the Scots pine seedlings after the second growing season (and none in the first year). During the first season, chemical treatment of the Scots pine seedlings against pine weevil feeding, along with the mineral-soil-covered mounds, protected the seedlings. However, the protective effect of such chemical treatment is reduced after the first year [38]. Nevertheless, the seedlings recovered relatively well from the feeding damage. Previously, deep planting has been reported to protect Norway spruce seedlings from pine weevil damage [29].

\section{Conclusions}

A deeper planting depth did not decrease the early field performance of small-sized silver birch or Scots pine seedlings in our study. This finding is in accordance with previous deep-planting results in boreal tree seedlings. Nevertheless, it must be acknowledged that our results consider only two field experiments in spot-mounded and inverted sites. Therefore, the deep planting of small-sized Scots pine and silver birch seedlings might potentially be good practice, at least on equivalent sites and with similar mechanical site preparation methods. At the deepest planting depth of $8 \mathrm{~cm}$ ( $9 \%$ of shoot above ground), a few Scots pine seedlings went missing, probably because they were accidentally planted too deeply and became completely buried. Based on our findings, the target planting depth for small-sized silver birch and Scots pine seedlings planted in mounds is the same as that previously recommended for taller conifer container seedlings planted in mounds-about $5-6 \mathrm{~cm}$. This would mean that $20 \%-40 \%$ of Scots pine shoots and $40 \%-50 \%$ of silver birch shoots would be above ground after planting. However, a longer inspection period is needed to be able to evaluate the long-term effects of planting depth on the quality and height growth of the seedlings.

Author Contributions: Conceptualization, L.P. and J.L.; methodology, L.P. and J.L.; formal analysis, L.P. and J.L.; investigation, L.P.; data curation, L.P.; writing —original draft preparation, L.P. and J.L.; writing - review and editing, L.P., J.L. and H.P.; visualization, L.P. and J.L.; project administration, L.P. and J.L.; funding L.P., J.L. and H.P. All authors have read and agreed to the published version of the manuscript.

Funding: This work was supported by the Natural Resources Institute Finland (Projects 4100700001300 and 41007-0012500), the Strategic Research Council of Academy of Finland (FORBIO project, grant number 314224) and the Jenny ja Antti Wihuri Foundation (scholarship for Laura Pikkarainen in 2020).

Institutional Review Board Statement: Not applicable.

Informed Consent Statement: Not applicable.

Data Availability Statement: The data underlying this article will be shared on reasonable request to the corresponding author.

Acknowledgments: We are grateful to Juhani Korhonen, Juhani Salonen, Liisa Kylmälä, Jukka Laitinen, Kari Kautto and Raimo Jaatinen for their assistance in the study.

Conflicts of Interest: The authors declare no conflict of interest. The funders had no role in the design of the study; in the collection, analyses, or interpretation of data; in the writing of the manuscript, or in the decision to publish the results. 


\section{Appendix A}
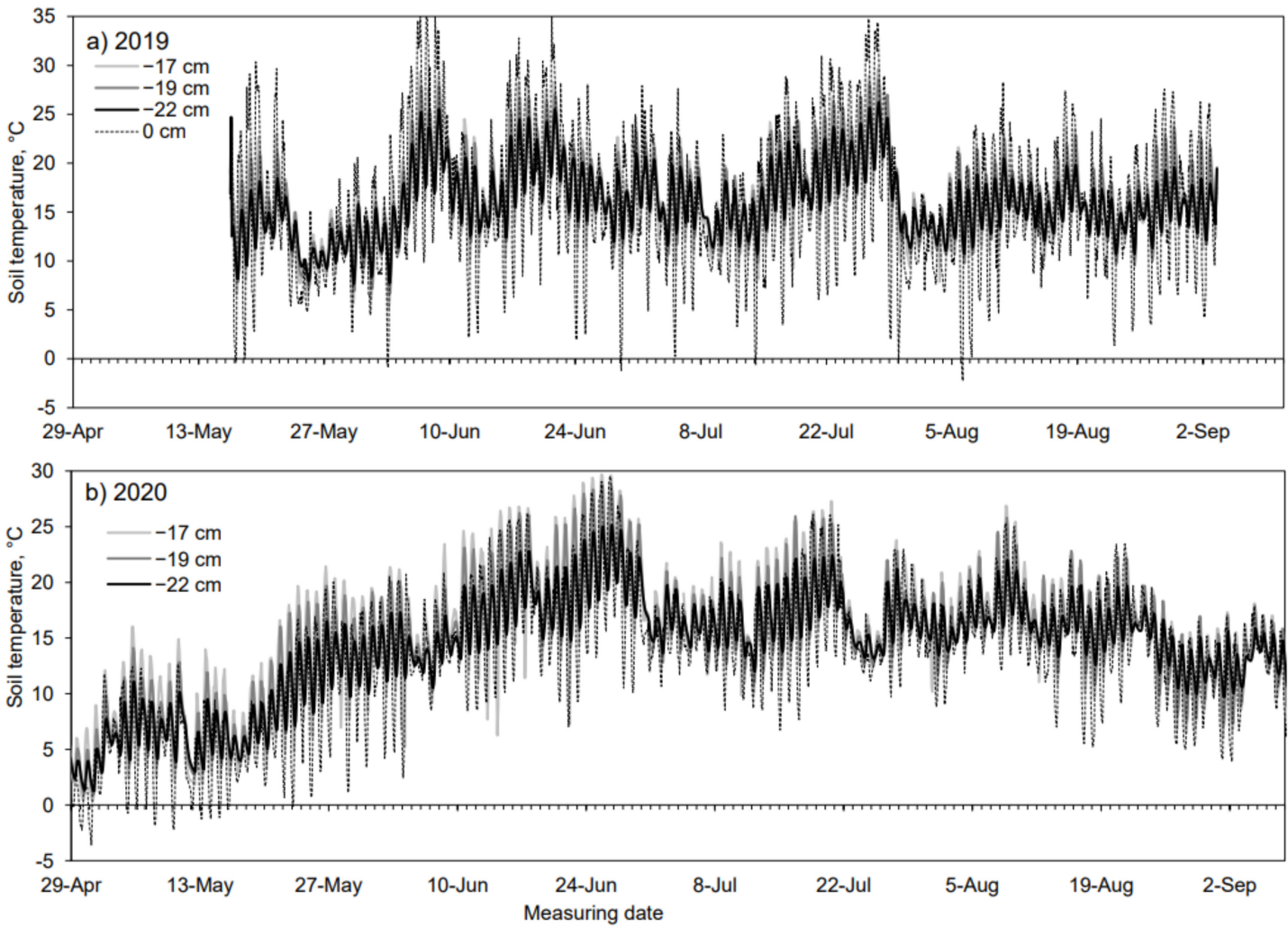

Figure A1. Soil temperatures at different planting depths during the growing seasons in (a) 2019 and (b) 2020 in the Scots pine experiment.

\section{References}

1. Seed and Seedling Statistics. Finnish Food Authority. 2019. Available online: http://stat.luke.fi/metsanhoito-jametsanparannustyot (accessed on 23 November 2020).

2. Netherer, S.; Schopf, A. Potential effects of climate change on insect herbivores: General aspects and a specific example (pine processionary moth, Thaumetopoea pityocampa). For. Ecol. Manag. 2010, 259, 831-838. [CrossRef]

3. Kellomäki, S.; Strandman, H.; Heinonen, T.; Asikainen, A.; Venäläinen, A.; Peltola, H. Temporal and spatial change in diameter growth of boreal Scots pine, Norway spruce and birch under recent-generation (CMIP5) global climate model projections for the 21st century. Forests 2018, 9, 118. [CrossRef]

4. Venäläinen, A.; Lehtonen, I.; Laapas, M.; Ruosteenoja, K.; Tikkanen, O.-P.; Viiri, H.; Ikonen, V.-P.; Peltola, H. Climate change induces multiple risks to boreal forests and forestry in Finland: A literature review. Glob. Chang. Biol. 2020, 26, $4178-4196$. [CrossRef]

5. Luoranen, J.; Rikala, R.; Smolander, H. Root egress and field performance of actively growing Betula pendula container seedlings. Scand. J. For. Res. 2003, 18, 133-144. [CrossRef]

6. Kumpare, T. Minitaimien hyvä kehitys jatkuu. Metsähallitus Kehittämisyksikön Tiedote 1998, 4, 1-2. (In Finnish)

7. Gyldberg, B.; Lindström, A. Kan små skogsplantor ge billigare och bättre för yngringar? Plantaktuellt 1999, 4, 1-2. (In Swedish)

8. Lindström, A.; Hellqvist, C.; Stattin, E. Mini seedlings-A new forest regeneration system. In The Thin Green Line: A Symposium on the State-of-the-art in Reforestation, Proceedings; Forest Research Information Paper 160; Colombo, J.S., Ed.; Ontario Forest Research Institute: Sault Ste Marie, ON, Canada, 2005; pp. 59-61.

9. Danielsson, M.; Kännaste, A.; Lindström, A.; Hellqvist, C.; Stattin, E.; Långström, B.; Borg-Karlson, A.K. Mini-seedlings of Picea abies are less attacked by Hylobius abietis than conventional ones: Is plant chemistry the explanation? Scand. J. For. Res. 2008, 23, 299-306. [CrossRef]

10. Johansson, K.; Nilsson, U.; Lee Allen, H. Interactions between soil scarification and Norway spruce seedling types. New For. 2007, 33, 13-27. [CrossRef]

11. Johansson, K.; Hajek, J.; Sjölin, O.; Normark, E. Early performance of Pinus sylvestris and Picea abies-A comparison between seedling size, species, and geographic location of the planting site. Scand. J. For. Res. 2015, 30, 388-400. [CrossRef] 
12. Luoranen, J.; Pikkarainen, L.; Poteri, M.; Peltola, H.; Riikonen, J. Duration Limits on Field Storage in Closed Cardboard Boxes before Planting of Norway Spruce and Scots Pine Container Seedlings in Different Planting Seasons. Forests 2019, $10,1126$. [CrossRef]

13. Sikström, U.; Hjelm, K.; Holt Hanssen, K.; Saksa, T.; Wallertz, K. Influence of mechanical site preparation on regeneration success of planted conifers in clearcuts in Fennoscandia-A review. Silva Fenn. 2020, 54, 10172. [CrossRef]

14. Hallsby, G.; Örlander, G. A comparison of mounding and inverting to establish Norway spruce on podzolic soils in Sweden. Forestry 2004, 77, 107-117. [CrossRef]

15. Smolander, A.; Heiskanen, J. Soil $\mathrm{N}$ and $\mathrm{C}$ transformations in two forest clear-cuts during three years after mounding and inverting. Can. J. Soil Sci. 2007, 87, 251-258. [CrossRef]

16. Buitrago, M.; Paquette, A.; Thiffault, N.; Bélanger, N.; Messier, C. Early performance of planted hybrid larch: Effects of mechanical site preparation and planting depth. New For. 2015, 46, 319-337. [CrossRef]

17. Gemmel, P.; Nilsson, U.; Welander, T. Development of oak and beech seedlings planted under varying shelterwood densities and with different site preparation methods in southern Sweden. New For. 1996, 12, 141-161. [CrossRef]

18. Paquette, A.; Girard, A.-P.; Walsh, D. Deep planting has no short- or long-term effect on the survival and growth of white spruce, black spruce, and jack pine. North J. Appl. For. 2011, 28, 146-151. [CrossRef]

19. Tarroux, E.; DesRochers, A.; Girard, J.-P. Growth and root development of black and white spruce planted after deep planting. For. Ecol. Manag. 2014, 318, 294-303. [CrossRef]

20. Nilsson, U.; Luoranen, J.; Kolström, T.; Örlander, G.; Puttonen, P. Reforestation with planting in northern Europe. Scand. J. For. Res. 2010, 25, 283-294. [CrossRef]

21. Luoranen, J.; Saksa, T.; Lappi, J. Seedling, planting site and weather factors affecting the success of autumn plantings in Norway spruce and Scots pine seedlings. For. Ecol. Manag. 2018, 419-420, 79-90. [CrossRef]

22. Huuri, O. Havupuiden istutusajankohdasta. Metsäntutkimuslaitos. Metsänviljelyn Koeaseman Tiedonantoja 1974, 12, 9-18. (In Finnish)

23. Valtanen, J.; Kuusela, J.; Marjakangas, A.; Huurinainen, S. Eri ajankohtina istutettujen männyn ja lehtikuusen kennotaimien alkukehitys. Folia For. 1986, 649, 1-17. Available online: http:/ / urn.fi/URN:ISBN:951-40-0732-8 (accessed on 12 November 2020). (In Finnish)

24. Luoranen, J.; Rikala, R. Field performance of Scots pine (Pinus sylvestris L.) seedlings planted in disc trenched or mounded sites over an extended planting season. New For. 2013, 44, 147-162. [CrossRef]

25. Luoranen, J. Autumn versus spring planting: The initiation of root growth and subsequent field performance of Scots pine and Norway spruce seedlings. Silva Fenn. 2018, 52, 1-15. [CrossRef]

26. Pikkarainen, L.; Luoranen, J.; Kilpeläinen, A.; Oijala, T.; Peltola, H. Comparison of planting success in one-year-old spring, summer and autumn plantings of Norway spruce and Scots pine under boreal conditions. Silva Fenn. 2020, 54, 10243. [CrossRef]

27. Örlander, G.; Gemmel, P.; Wilhelmsson, C. Effects of Scarification, Planting Depth and Planting Spot on Seedling Establishment in a Low-Humidity Area in Southern Sweden; In Swedish with English Summary; Report 33; Swedish University of Agricultural Sciences: Uppsala, Sweden, 1991.

28. Luoranen, J.; Viiri, H. Deep planting decreases risk of drought damage and increases growth of Norway spruce container seedlings. New For. 2016, 47, 701-714. [CrossRef]

29. Viiri, H.; Luoranen, J. Deep planting of Norway spruce seedlings: Effects on pine weevil feeding damage and growth. Can. J. For. Res. 2017, 47, 1468-1473. [CrossRef]

30. Luoranen, J.; (Natural Resource Institute, Suonenjoki, Finland). Personal communication, 2014.

31. Mullin, R.E. Influence of planting depth on survival and growth of red pine. For. Chron. 1964, 40, 384-391. [CrossRef]

32. Sutton, R.F. Influence of planting depth on early growth of conifers. Commonwealth For. Rev. 1967, 46, $282-295$.

33. Lindström, A.; Hellqvist, C.; Håkansson, L.; Stattin, E. Resultat Från Fältförsök Med Miniplantor 2003 Samt Återinventering av Äldre Försök; Stencil 36; Högskolan Dalarna, Institutionen för Matematik, Naturvetenskap och Teknik: Falun, Sweden, 2004; 22p. (In Swedish)

34. Lyr, H.; Hoffmann, G. Growth rates and growth periodicity of tree roots. Int. Rev. For. Res. 1967, 2, 181-206. [CrossRef]

35. Kalliokoski, T.; Nygren, P.; Sievänen, R. Coarse root architecture of three boreal tree species growing in mixed stands. Silva Fenn. 2008, 42, 189-210. [CrossRef]

36. Ruosteenoja, K.; Markkanen, T.; Venäläinen, A.; Räisänen, P.; Peltola, H. Seasonal soil moisture and drought occurrence in Europe in CMIP5 projections for the 21st century. Climate Dynamics 2018, 50, 1177-1192. Available online: https://link.springer.com/ article/10.1007/s00382-017-3671-4 (accessed on 8 December 2020). [CrossRef]

37. Tuttle, C.L.; South, D.B.; Golden, M.S.; Meldahl, R.S. Relationship between initial height and survival and growth of loblolly pine seedlings planted during a droughty year. South J. Appl. For. 1987, 11, 139-143. [CrossRef]

38. Viiri, H.; Tuomainen, A.; Tervo, L. Persistance of deltamethrin against Hylobius abietis on Norway spruce seedlings. Scand. J. For. Res. 2007, 22, 128-135. [CrossRef] 